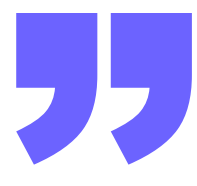

\title{
TYPES OF CODE SWITCHING FOUND IN THE TWITTERS OF THE INDONESIAN KPOP FANS
}

\author{
Ni Putu Liana Ariasih ${ }^{1}$, I Made Iwan Indrawan Jendra ${ }^{2}$, and I Komang \\ Sulatra ${ }^{3}$ \\ Mahasaraswati Denpasar University, Indonesia ${ }^{123}$ \\ lianaariasih11@gmail.com,_ iwanindrawanjendra73@yahoo.com, \\ soelatra01@yahoo.com
}

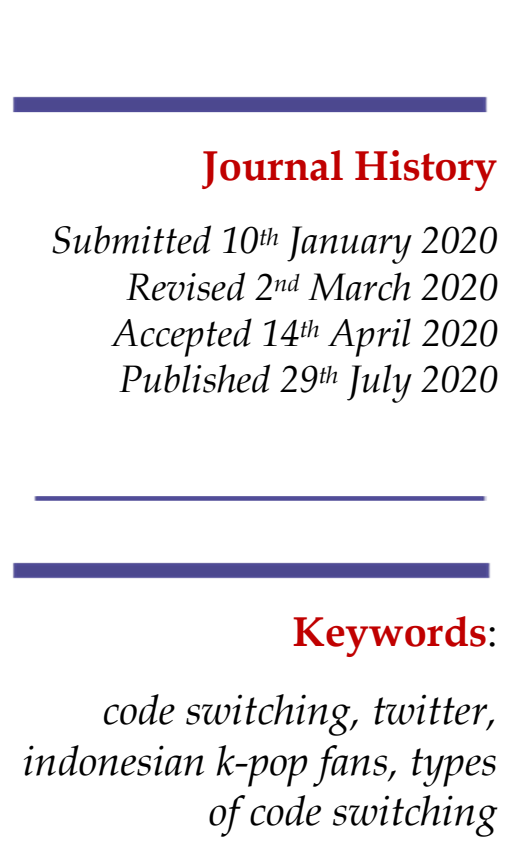

\begin{abstract}
This study aims to find out the types of the code switching occur in the tweets posted by the Indonesian K-Pop Fans on Twitter. As the phenomenon of code switching in social media is very common nowadays, it makes the writer interested in doing this research. The fifteen data were collected and analyzed by using descriptive qualitative method. In analyzing data, the writer uses the theory proposed by Poplack (1980). The result of this study shows that from fifteen tweets only two types of code switching were found namely inter-sentential switching and intra-sentential switching.
\end{abstract}

\section{INTRODUCTION}

In this digital era, people can't be separated from the use of social media. Social media has become the primary need because without the existence of social media, they can't communicate and do interaction online. One examples of social media is Twitter. Twitter is a free micro blogging application that allows registered members to post what are in their mind. When we post in this application, our content will be called as tweets. Twitter users can post, like, retweet, quote and reply to the tweet. They also can follow other users and interact with them (Rouse, Margaret 2015). 
Twitter has become one of the biggest platforms of communication for the fan communities. As Korean Wave continues to influence the global entertainment, Indonesia becomes the home of many biggest fans of K-Pop. The fandom data observatory conducted by K-Pop Radar in collaboration with Twitter, found that Indonesia ranked in the best three nations with the biggest volume of K- pop tweets between July 1, 2019 and June 30, together with Thailand and South Korea. The Twitter account of the Korean Pop star NCT has 4.8 million followers in Indonesia. The K-Pop Fans use Twitter to communicate with each other and help to spread the K-Pop culture to people from different parts of the world. "Korean fans tend to use Twitter to share information and emotions toward their favorite celebrities' due to its rapid speed in uploading information on the web" (Razak, et al., 1).

The Indonesian K-Pop Fans are mostly bilinguals. In talking about their favorite idol on Twitter, they tend to switch their language from Indonesian to English or vice versa. When they do switch, they also use some language functions in it. For example, from the account @flowwkun who said "pagi-pagi baru ngeliat preview yosahi" which shows the occurrence of referential function. Other example comes from the account @luxucicas "baru ngerasain dreamies bertujuh I'm so happy" which shows the occurrence of expressive function. Occurrence of the functions of code switching in the tweet of the Indonesian K-Pop Fans has made the writer become interested in studying the code switching. In this study, the researcher would focus on analyzing the type of code switching used by the Indonesian K-Pop Fans on their tweets.

In this study, the researcher also reviewed some related literature to share to the reader about the result of other studies that are closely related to the one being undertaken. The relevant studies reviewed are presented below:

The first research was conducted by Tajudin (2013) entitled “The Occurrence Of Code Switching On Personal Message Of Blackberry Messenger". The study focused on analyzing the types and the reasons of code switching used on personal message of BlackBerry messenger. In analyzing the problem, he referred to the theory proposed by Poplack (1980), Hoffman (1991 in Tiana, 2009) and Savile-Troike (1986). His study is similar to this study in the terms of analyzing code switching in social media. However, it has different data source. His study is focused on code switching used on BlackBerry Messenger but this study is focused on code switching used on Twitter. According to the result of the study, it showed that inter-sentential switching is the most dominant type with the number of percentages $(40.63 \%)$. For the reason of code switching, the most dominant is for real lexical need with the number of percentages $(24 \%)$. 
The second research was conducted by Luthfiyani (2014) entitled "Code Switching and Code Mixing On Korean Television Music Show After School Club". Her study is focused on analyzing the types and the influential factors of code mixing and code switching in music show After School Club. In analyzing the problem, she referred to the theory proposed by Holmes (2001) and Saviel-Troike (1982). Her study is similar to this study in term of analyzing the data because both researches used descriptive qualitative. The difference between her study and this study are, her study focused on both code switching and code mixing but this study only focused on code switching. The data source of her study was taken from Korean Television Music Show After School Club meanwhile the data source of this research was taken from social media Twitter. The result of her study showed that there were 7 utterance can be classified as code mixing and 9 utterances as code switching. The most frequent factors that influencing code mixing and code-switching phenomenon is the change of particular participant or topic in the conversation.

Last, the research was conducted by Rianda (2017) entitled "Code Switching and Code Mixing Used By Boy William In Breakout Music Program At Net Tv". She focused on analyzing the types and the reasons of code mixing and code switching used by Boy William. She used the theory proposed by Poplack (2004) and Hoffman (1991). Her study is similar to this study that it used descriptive qualitative method. The difference between her study and this study are, her study focused on both code switching and code mixing but this study only focused on code switching. The findings showed that insertion code mixing is the most frequently used by Boy William. There were 8 reasons of using code switching and code mixing: talking about a particular topic, quoting somebody else, being emphatic about something, interjection, repetition, intention of clarifying the speech content for interlocutor, expressing group identity, and because of lexical need.

\section{METHODS}

The data source of this research was taken from the Indonesian KPop Fans' utterance on their tweets. The data sources were 10 Twitter accounts of Indonesian K-Pop Fans: @ilyseongmin, @jaeminlight_, @cuteleaderkun, @flowwkun, @binjinpeach, @sweetxgrass, @goldenyukhei, @minheebrows, @luxuxicas, and @doiechingu. The number of tweets posted in each account is more than 2.000 tweets. Thus, only 15 tweets were selected from 10 accounts posted from October 2020 to November 2020. In collecting the data, observation method was applied in this research. The observation was done in some steps as follows:

1. Twitter application was opened. 
2. 10 accounts of Indonesian K-Pop Fans were choosing selectively.

3. Their profile accounts were observed one by one

4. Their profile was scrolled and their tweets were read carefully.

5. When finding the tweets with code switching, the tweets were screen shot by the writer.

6. The screenshots were read carefully and the writer determined which types of code switching were there in those tweets.

The descriptive qualitative method was used to analyze the data in this research. The writer analyzed the types of code switching that was found in the tweets by referring to the theory proposed in Poplack (1980). Then, the conclusion of the types of code switching was drawn based on the result of data analysis.

\section{RESULTS AND DISCUSSION}

\section{RESULT}

Table 1 The Occurrence of The Types of Code Switching and The Example Data

\begin{tabular}{l|lcl} 
No & \multicolumn{1}{|c}{$\begin{array}{c}\text { Types of Code } \\
\text { Switching }\end{array}$} & Occurrence & \multicolumn{1}{c}{ Examples of Data } \\
\hline 1. & $\begin{array}{l}\text { Intra-sentential } \\
\text { switching }\end{array}$ & 10 & $\begin{array}{l}\text { pagi pagi baru ngeliat } \\
\text { preview yosahi }\end{array}$ \\
\hline 2. & $\begin{array}{l}\text { Inter-sentential } \\
\text { switching }\end{array}$ & 8 & $\begin{array}{l}\text { baru ngerasain dreamies } \\
\text { bertujuh I'm so happy }\end{array}$ \\
\hline 3. & Tag Switching & - & \\
\hline TOTAL & $\mathbf{1 8}$ &
\end{tabular}

Table 1 shows the occurrence and the example data of the types of code switching found in the tweets. The total of the data was 18. Based on the table, there were 10 intra-sentential switching and 8 inter-sentential switching. Intra-sentential switching became the most frequently found types because the Indonesian K-Pop Fans often added English words in the middle of their utterance. Inter-sentential switching became the least found function because the Indonesian K-Pop Fans rarely switch their utterance within the sentence boundary. Unfortunately, Tag switching couldn't be found in the tweets because the Indonesian K-Pop Fans didn't add a tag or short phrase to their utterance. 


\section{DISCUSSION}

\section{Data 1}

$\leftarrow \quad$ Tweet

알라뷰

efek mata udah cape seharian

liatin laptop apa gimana ya

thought this was minhee...

Figure 1 The Indonesian K-Pop Fans mistook another idol as her favorite idol

"Efek mata udah cape seharian liatin laptop apa gimana ya thought this was minhee..."

(Maybe this is the effect of tired or something thought this was minhee...)

The insertion of English clause "thought this was minhee..." after the Indonesian sentence in the tweet above shows the occurrence of intersentential switching. The sentence was started with "efek mata udah cape seharian liatin laptop apa gimana $y a^{\prime \prime}$. Then, it was continued with the English "thought this was minhee".

\section{Data 2}

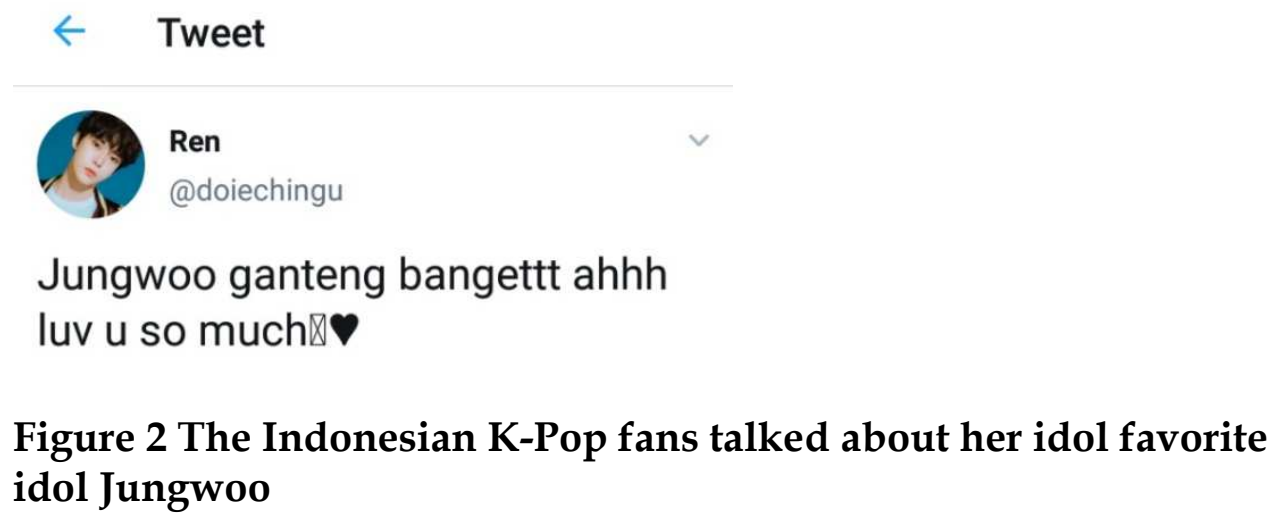




$$
\begin{aligned}
& \text { “jungwoo ganteng bangettt ahhh luv u so much" } \\
& \text { (jungwoo is so handsome ahhh luv u so much) }
\end{aligned}
$$

The tweet above shows there is an insertion of English sentence in the end of the Indonesian sentence. The sentence was started with Indonesian "Jungwoo ganteng bangettt ahhh". Afterward it was continued

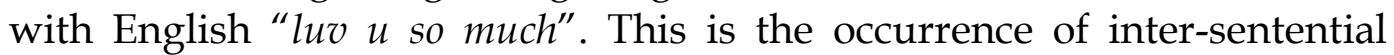
switching.

\section{Data 3}

$\leftarrow$ Tweet
@zzı @ip
pagi pagi baru ngeliat preview
yosahi

Figure 3 The Indonesian K-Pop Fans talked about Yosahi's preview

"pagi-pagi baru ngeliat preview yosahi"

(recently seeing yosahi preview in the morning)

The switching in the tweet above can be categorized as intrasentential switching because there is an insertion of English clause in the end of the Indonesian sentence. The sentence was started in Indonesian "Pagi-pagi baru ngeliat". Afterward, it was inserted with English phrase "preview yosahi".

\section{Data 4}

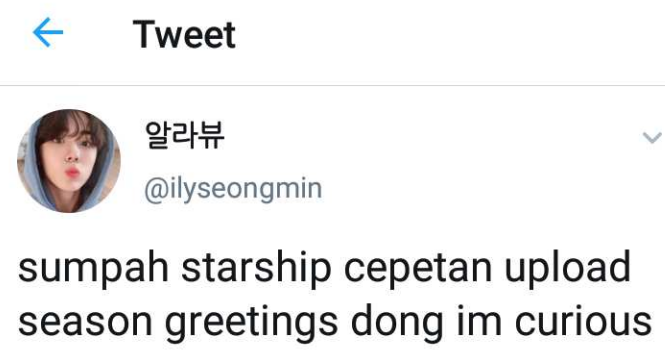


Figure 4 The Indonesian K-Pop Fans told Starship Entertainment to upload the season greetings as soon as possible

"sumpah starship cepetan upload season greetings dong im curious"

(please starship uploads the season greetings as soon as possible im curious)

Intra-sentential switching has been occurred in this tweet by adding an English clause in the middle of the sentence. The sentence was started in Indonesian "sumpah starship cepetan" which was continued with English phrase "upload season greetings". Then, it was added with Indonesian word "dong". Another type of code switching that is inter-sentential switching also occurred in this tweet by adding English words "I'm curious" in the end of the sentence. In conclusion, the tweet above has two types of code switching; intra-sentential switching and inter-sentential switching.

\section{Data 5}

$\leftarrow$ Tweet

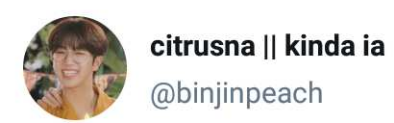

Minhee nonton fancam nya

Yunseong

Figure 5 The Indonesian K-Pop Fans talked about her idol Minhee

"Minhee nonton fancam nya Yunseong"

(Minhee watches Yunseong's fancam)

Intra-sentential switching has been occurred in this tweet by adding an English phrase in the middle of the sentence. The sentence was started in Indonesian "Minhee nonton" which was continued with English phrase "fancam nya Yunseong". 


\title{
Data 6
}

\author{
$\leftarrow \quad$ Tweet

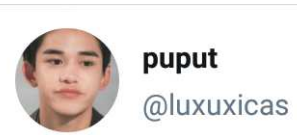 \\ baru ngerasain dreamies ber \\ tujuh \\ I'm so happy
}

Figure 6 The Indonesian K-Pop Fans talked about her idol dreamies

"baru ngerasain dreamies bertujuh I'm so happy"

(finally, I can feel dreamies seven formation I'm so happy)

The tweet above shows there is an insertion of English sentence in the end of the Indonesian sentence. The sentence was started with Indonesian "baru ngerasain dreamies bertujuh". Afterward it was continued with English "I'm so happy". This is the occurrence of inter-sentential switching.

\section{Data 7}

\author{
$\leftarrow$ Tweet

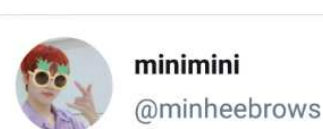 \\ I think.... gadapet minhee maupun \\ hyeongjun tapi gatau kalo luck \\ masih ngikutin pasti nanti \\ nyangkut salah satu... semoga \\ aja (-0) $\square$
}

Figure 7 The Indonesian K-Pop Fans talked about her luck in getting her favorite idol photo card

"I think.... Gadapet minhee maupun hyeongjun tapi gatau kalo luck masih ngikutin pasti nanti nyangkut salah satu... semoga aja" 
(I think.... I won't get minhee or hyeongjun but I don't know if I being lucky, I still follow it hopefully I can get one of them)

Because the switch happens within the sentence, the tweet above can be categorized as inter-sentential switching. It can be seen from the switch from English to Indonesian in the sentence boundary. The switch was started by uttering English "I think....". Afterward, it was continued by uttering Indonesian "gadapet minhee maupun hyeongjun".

In the tweet above there is also an insertion of English words "luck" within the Indonesian sentence. The sentence was started in Indonesian "tapi gatau kalo". Then, it was inserted with English word "luck". The sentence was ended in Indonesian "masih ngikutin pasti nanti nyangkut salah satu... semoga aja". It shows the occurrence of intra-sentential switching.

\section{Data 8}

$\leftarrow$ Tweet

7. jaemin black hair better than my life

17y @sweetxgrass

WINWIN SHINE BRIGHT I'M ALIVE

Apaan sie $\mathrm{QWQ}$

Figure 8 The Indonesian K-Pop Fans talked about her favorite idol Winwin

“WINWIN SHINE BRIGHT I'M ALIVE Apaan sie"

(WINWIN SHINE BRIGHT I'M ALIVE what are you talking about)

The use of full English in the beginning of the tweet "WINWIN SHINE BRIGHT I'M ALIVE...." and then it was followed by Indonesian "...Apaan sie" showed the occurrence of inter-sentential switching. The switching in the tweet above indicated a switch in the sentence boundary. Thus, it can be said that the tweet can be categorized as inter-sentential switching.

\section{Data 9}




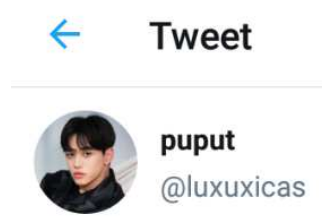

jeno blue hair? gila gila udah

Figure 9 The Indonesian K-Pop fans talked about Jeno's hair color

"jeno blue hair? gila gila udah"

(jeno blue hair? no way, this is crazy)

The occurrence of intra-sentential switching has been shown in this tweet because there is an insertion of English word in the beginning of Indonesian sentence. The sentence started in English "jeno blue hair?". Then, it was continued with the Indonesian sentence "gila gila udah". Thus, it can be categorized as intra-sentential switching.

\title{
Data 10
}

\author{
$\leftarrow$ Tweet \\ ajaeminlight_ \\ Mark jungwoo lucas for sun \& \\ moon?? \\ Ohhh kirain gak bakal ada yg \\ double.. BERARTI OOL WITH SUN \\ \& MOON SOON YESYES
}

Figure 10 The Indonesian K-Pop Fans talked about her idol who will appear on Sun \& Moon program

"Mark jungwoo lucas for sun \& moon? Ohh kirain gak bakal ada yg double..BERARTI OOL WITH SUN \& MOON SOON YESYES”

(Mark jungwoo lucas for sun\&moon? Ohh I thought there won't be double appearance.. It means OOL WITH SUN\&MOON SOON YESYES) 
The data above presents some types of code switching. The first utterance showed intra-sentential switching because there is an insertion of Indonesian clause in the middle of English sentence. The tweet was started in English "Mark jungwoo lucas for sun \& moon?". Then, it was inserted with Indonesian "Ohh kirain gak bakal ada $y g^{\prime \prime}$. Finally, the tweet was ended by adding an English word "double".

The last utterance "BERARTI OOL WITH SUN \& MOON SOON YESYES" which was started in Indonesian and then, it was written in full English showed another type of code switching that is inter-sentential switching because the switch happened within the clause. Switching within the sentence or phrase can be the place for inter-sentential switching.

\section{CONCLUSION}

After the data were analyzed, it can be concluded that there were two types of code switching used by the Indonesian K-Pop Fans on their tweets. Those were inter-sentential switching and intra-sentential switching. The distribution of each functions in the tweets were not the same. Intrasentential switching became the most frequently found types with 10 total data. It was followed by inter-sentential switching in the second place with 8 total data. Unfortunately, Tag switching couldn't be found because the Indonesian K-Pop Fans rarely add tag or short phrase to their tweets.

\section{ACKNOWLEDGMENT}

The researcher would like to express her highest gratitude to Ida Sang Hyang Widhi Wasa for His bleesing, love, opportunity, health, and mercy therefore this article can be finished on time. In making this article, a lot of people have provided motivations, advices and also support that had helped the researcher. In this important chance, the researcher would like to express her gratitude and appreciation to all of them who have made important contributions in making this article. Dr. I Made Iwan Indrawan Jendra, S.S., M.Hum. as the first supervisor and I Komang Sulatra, S.S., M.Hum. as the co-supervisor, for their suggestions, criticism, advices, comments, and many corrections in the process of making this article. My beloved parents and also my brother, for all love, pray and support that were given to me. My beloved Korean idols Rano from E'LAST, Gun from ENOi, Intak from P1Harmony, Woong from AB6IX, Jinwoo from GHOST9, Junghwan from BDC, Jun from A.C.E, Taeyong from NCT, Yangyang from WayV, Shotaro from NCT, Wooyoung from ATEEZ, Yonghoon from ONEWE, Xion from ONEUS, Chen from EXO, Seongmin from Cravity and Yechan from LUCY, for always encourage me through their songs and words. All of my precious online friends on Twitter for always supporting 
and motivating me. The researcher realizes that this article is still far from perfection. Any kind of comment and suggestion are needed to improve the quality of this article. Finally, this article is expected to be useful for those who are interested in linguistic research, especially in the field of sociolinguistics

\section{REFERENCES}

Appel, R. and Muysken, P., 1987. Language Contact And Bilingualism. London: Arnold, Edward

Derseh, M., 2019. Fandom And Its Influence On Korean Entertainment. Medium. Retrieved October 26, 2020 from https://medium.com/meron-d3r53h/fandom-and-its-influenceon-korean-entertainment-50fe19be513b

Holmes, J., 2003. An Introduction To Sociolinguistics. 4th ed. New York: Routledge.

Journal Of English And Education, 2013. The Occurrence Of Code Switching On Personal Message Of Blackberry Messenger.

Luthfiyani, Fithria.2014. “Code Switching And Code Mixing On Korean Television Music Show After School Club". Jakarta: English Letters Department, Letters And Humanities Faculty, State Islamic University Of Syarif Hidayatullah. Retrieved from www.repository.uinjkt.ac.id/dspace/bitstream.

Myers-Scotton, C., 2006. Multiple Voices An Introduction To Bilingualism. Blackwell Publishing.

Post, T., 2020. Indonesians Among K-Pop's Biggest Fans: Twitter. The Jakarta Post. $\quad$ Retrieved from https:www.thejakartapost.com/life/2020/09/23/Indonesiansamong-k-pops-biggest-fans-twitter.html

Rianda, Dara. 2017. "Code Switching And Code Mixing Used By Boy William In Breakout Music Program At Net Tv". Palangkaraya: Department Of Language Education, Faculty Of Tarbiyah And Educational Science, State Islamic Institute Of Palangkaraya. Retrieved from digilib.iain-palangkaraya.ac.id/1098/1/SKRIPSI DARA RIANDA.pdf

$\begin{array}{llll}\text { Twitter. 2020. 알라부. } & \text { Retrieved from }\end{array}$ https:/ / twitter.com/ilyseongmin?s=20

$\begin{array}{llll}\text { Twitter. 2020. Cipanana. } & \text { Retrieved }\end{array}$ https:/ / twitter.com/sweetxgrass?s=20 
Twitter.

2020.

Citrusna.

Retrieved

from https:/ / twitter.com/ binjinpeach?s=20

Twitter. 2020. Dizzy. Retrieved from https:// mobile.twitter.com/flowwkun?s=20

Twitter. 2020. Dila. Retrieved from https://twitter.com/jaeminlight_?s=20

Twitter 2020. $\mathrm{Mei}$ Mei.

Retrieved from https:/ / twitter.com/cuteleaderkun?s=20

$\begin{array}{llll}\text { Twitter. } 2020 . & \text { Minimini. } & \text { Retrieved }\end{array}$ https://twitter.com/minheebrows?s=20

Twitter. 2020. NCT. Retrieved from https://twitter.com/NCTsmtown?s=1

Twitter. 2020. Puput. Retrieved from https://twitter.com/luxuxicas?s=20

Twitter. 2020. Ren. Retrieved from https://twitter.com/doiechingu?s=20

Twitter. 2020.Ugi. Retrieved from https://twitter.com/goldenyukhei_?s=20 